\title{
Designing Virtual Learning Media for a Vocational School
}

\author{
Sutaryadi Jumiyanto Widodo*, Chairul Huda Atma D, \\ Arif Wahyu Wirawan, Sigit Permansah \\ Office Administration Education, Teacher Training and Education Faculty, \\ Universitas Sebelas Maret Surakarta \\ *Email: sutaryadi@staff.uns.ac.id
}

\begin{abstract}
Developments in the areas of science and information technology affect the industrial and educational realms in Indonesia. Technological advances require teachers as educators to create innovative virtual learning media that can support students' understanding either theoretically or practically. Considering the results of this observational study, it is confirmed that virtual learning has not been implemented widely in the Vocational School. Virtual learning media are an aid used to explain curriculum content that enables students to better understand the material either theoretically or practically. Virtual learning media have been incorporated into courses in personnel administration. This study explores whether virtual learning media improves students' learning interest, motivation, and outcome.
\end{abstract}

Keywords: virtual learning media, personnel administration, Vocational school

\section{Introduction}

Developments in science and technology affect the world's industrial and educational realms, including Indonesia. Technology exerts a positive effect not only in social life but also in education. With the increasing prevalence of digital technology in educational organizations, teachers are expected to utilize these resources to support the teaching-learning process in the classroom (Akyuz \& Yavuz, 2015; Gan, Menkhoff, \& Smith, 2015; All, Nuñez Castellar, \& Van Looy, 2015). The utilization of such resources can be observed from the learning infrastructure and media a teacher uses in delivering material to students. Advances in technology challenge teachers to continuously innovate learning media that can support understanding either theoretically or practically (Kingsley, 2007; Norman \& Furnes, 2015; Kartikasari, 2016). The use of learning media, in addition to facilitating classroom delivery, can also increase the students' willingness and interest in a subject. Therefore, the application of virtual learning media in education has become very desirable.

The appropriate learning applied in the 2013 curriculum emphasizes on learning by doing as an attempt of practicing the students' competency. Such the competency is expected to improve the students' problem solving and critical thinking abilities in the learning process. In the learning process, competency can be implemented through scientific approach including observing, questioning, presenting, reasoning, and trying. The competency can be maximized by applying student-centered learning, so that the students can learn independently in solving the problem given during learning process.

The results of a field survey on the business and management specialty of the Vocational School in Surakarta Ex-Residency area found that teachers in the office administration specialty program still use traditional learning media for presenting theory under the 2013 Vocational School curriculum. Business and management courses were also found to make sub-optimal use of virtual learning media as an aid to the teaching process as required for implementation of the Vocational School's 2013 curriculum, which is focused on raising student competency.

The students have less optimal competency in office administration learning activity. Student competency comprises their knowledge, skills, and attitude toward the subject and the learning process. Knowledge is reflected students' mastery of the course content. Skills indicate proficiency (ability) that can be seen from practical material mastery. Attitude is students' disposition toward the learning process that can be assessed observationally.

Office administration-virtual learning media is designed in the class (computer laboratory) using Microsoft Access media, so that interaction occurs between students, between students and media, and between students and teachers. A virtual learning model is designed that combines face-to-face interactions and electronic learning to improve students' involvement and contribution. Mature preparation before implementing virtual learning plays an important part in making the learning process run smoothly. Preparation, including scheduling 
and communication technique determination during the learning process, is important in implementing the virtual learning.

Considering the aforementioned learning scenario, this research aims to obtain Office Administration-Virtual Learning Media in Vocational School. The result of research is expected to be the reference to Vocational School in the 2013 curriculum-based learning.

\section{Method}

Data for this study were collected using a survey questionnaire for students and teachers, in-depth interviews, passive observation of learning activities, and document analysis of teaching materials etc. The research was conducted in the Office Administration department of the Vocational School in Surakarta ExResidency area. Qualitative data were analyzed using an interactive model of analysis (Miles \& Huberman, 1992:20).

\section{Results and Discussion}

This virtual learning media development aims to explain and to give the students, particularly vocational school students, learning understanding in Office Administration field. Virtual learning media is one of learning media appropriate to use in practical activity in vocational school environment.

Several learning difficulties are identified as follows: limited learning media and sources; students feeling bored quickly with the teaching-learning process because the learning is verbal in nature; incompatibility of learning material to real-world job needs; limited learning time in the class, and students finding difficulty in listening to teachers' explanation while recording what teachers explain or write (Prasetya \& Subagyo, 2016; Arnanto, 2014; Musakkir, 2015). Learning media are used to channel messages (learning material) attractively (Sanjaya \& Suparmin, 2017) in order to stimulate students' attention, interest, thinking, and feeling in the learning activity and, thereby, achievement of the learning objective. Virtual/Digital learning media are integral components of the modern learning system, meaning that learning media are inseparable from learning process. Formulating rational thinking about the importance of developing media and studying theories underlying the media development as included in the literature review.

Considering the result of observation conducted, as shown in the need analysis phase, it can be concluded that teachers find difficulty in delivering learning material. Learning material is personnel administration subject, in which there has been no learning media appropriate to the material so that a Microsoft Access-based virtual learning media is developed in the form of employee data processing system. Teachers also find difficulty in developing learning media thereby providing visual example less maximally to the students. Therefore, there should be learning media development adjusted with the learning material in Office Administration Specialty of Vocational School. It should be supported with adequate infrastructure such as an LCD projector, laptop, or computer that can be used easily by students. This learning media can be used independently by students; through learning media development. When students can master the material well and are motivated, their learning outcomes will improve (Sangsawang, 2015; Turyati, Moh, Muchtarom, \& Winarno; Kartikasari, 2016; Musakkir, 2015; Sukiyasa \& Sukoco, 2013; Arnanto \& Triyono, 2014).

Curriculum Analysis is conducted by formulating instructional objective based on basic competency and indicator included in curriculum about a material concept, followed with material analysis in which the activity conducted is to identify, to detail, and to organize the concept systematically for learning material. Material analysis is conducted to find out the conception the students should master to achieve basic competency and learning objective.

Media designing, selecting, and using stages involve the description of abstract condition corresponding to objective, concept, environment condition, and facility as well as time provided for learning need. Virtual learning media are designed using Microsoft Access software. The author uses Microsoft Access media in this study as it facilitates the organizing of material to be presented to the students. Product design and media products are developed as well, and as attractively as possible to produce a good teaching-learning product that can be used in the classroom.

Database used in virtual learning media of personnel administration is a design of application or system facilitating the storage of personal data archive digitally. In addition to aiming to be virtual learning media of office administration in vocational school, media development is used to facilitate the delivery of personnel system practical material virtually.

The design of virtual learning media development has been adjusted with personnel system existing in the personnel system in work realm, so that it can be used in teaching-learning process, particularly as practical activity using personnel system all features of which are developed according to the material the teachers deliver. 


\section{Conclusion}

Innovative teaching is very desirable in creating a positive learning environment. Learning innovation can result in learning media that create a joyful learning circumstance and a format that is acceptable to the students. As information and communications technology advances, teachers are required to update their teaching material.

Virtual learning media are used to deliver learning material, both theoretically and practically, in the Vocational School's personnel administration course. Personnel administration is one of four specialty subjects studied in the Office Administration department, in addition to financial administration, infrastructure administration, public relations, and protocol administration. In personnel administration subject, there is personnel administration practice, one of which is implemented with some data inputs such as grading system, position, and employees' personal data in an office. This virtual learning media is very appropriate to use in practical learning as it is can be used and developed easily by teachers.

\section{Acknowledgment}

We wish to thank Subject Teacher Discussion (MGMP) of Office Administration teachers throughout Surakarta Ex-Residency.

\section{References}

Akyuz, S., \& Yavuz, F. (2015). Digital learning in EFL classrooms. Procedia-Social and Behavioral Sciences, 197, 766769. doi: 10.1016/j.sbspro.2015.07.176.

All, A., Nuñez Castellar, E. P., \& Van Looy, J. (2016). Assessing the effectiveness of digital game-based learning: Best practices. Computers and Education, 92-93, 90-103. doi: 10.1016/j.compedu.2015.10.007.

Arnanto, G. C. (2014). Keefektifan Pembelajaran berbantuan internet di smk se-kota Yogyakarta Kompetensi Keahlian Teknik Komputer dan Jaringan. Jurnal Pendidikan Vokasi, 4(3), 318-332.

Gan, B., Menkhoff, T., \& Smith, R. (2015). Enhancing students' learning process through interactive digital media: New opportunities for collaborative learning. Computers in Human Behavior, 51(Part B), 652-663. doi: 10.1016/j.chb.2014.12.048.

Kartikasari, G. (2016). Pengaruh media pembelajaran berbasis multimedia terhadap motivasi dan hasil belajar materi sistem pencernaan manusia studi eksperimen pada siswa kelas v mi miftahul huda pandantoyo. Jurnal Dinamika Penelitian, 16(1), 59-77. doi: 10.21274/dinamika.2016.16.1.59-77

Lock, R. H., \& Kingsley, K. V. (2007). Empower diverse learners with educational technology and digital media. Intervention in School and Clinic, 43(1), 52-56. doi: 10.1177/10534512070430010701.

Miles, M. B. \& Huberman, M. A. (1992). Analisis data kualitatif: buku sumber tantang metode-metode baru. Jakarta:UI Press.

Musakkir. (2015). Pengaruh media pembelajaran dan motivasi belajar terhadap hasil belajar matematika siswa kelas iv sekolah dasar kabupaten tanah tidung. Jurnal Pendidikan Dasar, 6(1), 36-47.

Norman, E., \& Furnes, B. (2016). The relationship between metacognitive experiences and learning: Is there a difference between digital and non digital study media? Computers in Human Behavior, 54, 301-309. doi: 10.1016/j.chb.2015.07.043.

Prasetya, A., \& Subagyo. (2016). Penggunaan media audio visual untuk meningkatkan motivasi dan hasil belajar mata pelajaran sistem bahan bakar motor bensin siswa kelas xi tsm di smk bina mandiri klampok banjarnegara tahun ajaran 2015/2016. Jurnal Taman Vokasi, 4(1), 51-56.

Sangsawang, T. (2015). Instructional design framework for educational media. Procedia - Social and Behavioral Sciences, 176, 65-80. doi: 10.1016/j.sbspro.2015.01.445.

Sanjaya, S., \& Suparmin. (2017). Penerapan media pembelajaran lectora inspire untuk meningkatkan minat dan prestasi belajar perhitungan konstruksi mesin siswa kelas xi mesin di smk piri sleman. Jurnal Taman Vokasi, 5(1), 56-61.

Sukiyasa, K., \& Sukoco. (2013). Pengaruh media animasi terhadap hasil belajar dan motivasi belajar siswa materi sistem kelistrikan otomotif. Jurnal Pendidikan Vokasi, 3(1), 126-137.

Turyati, Moh, Muchtarom, \& Winarno. (2016). Pengaruh penggunaan media video edukasi terhadap hasil belajar pkn siswa kelas Vii smp negeri 2 gondangrejo. PKn Progresif, 11(1), 256-267. 